\title{
Nuclear Medicine Imaging Technique in the Erectile Dysfunction Evaluation: A Mini-Review
}

\author{
Camila Godinho Ribeiro ${ }^{1}$, Regina Moura ${ }^{1}$, Rosane de Figueiredo Neves ${ }^{1}$, Jean Pierre Spinosa ${ }^{2}$ and \\ Mario Bernardo-Filho ${ }^{1,3}$ \\ ${ }^{1}$ Laboratório de Radiofarmácia Experimental; Departamento de Biofísica e Biometria; Instituto de Biologia \\ Roberto Alcantara Gomes; Universidade do Estado do Rio de Janeiro; Av. 28 de setembro, 87; \\ cacagr@yahoo.com.br; 20551-030; Rio de Janeiro - RJ - Brasil. ${ }^{2}$ Department of Gynecology and Obstetrics; \\ Hopital de Zone, 1110; Morges - Switzerland. ${ }^{3}$ Coordenadoria de Pesquisa; Instituto Nacional do Câncer; Praça \\ Cruz Vermelha, 23; 20230-130; Rio de Janeiro - RJ - Brasil
}

\begin{abstract}
Functional imaging with positron emission tomography and single photon emission computed tomography is capable of visualizing subtle changes in physiological function in vivo. Erectile dysfunction(ED) diminishes quality of life for affected men and their partners. Identification of neural substrates may provide information regarding the pathophysiology of types of sexual dysfunction originating in the brain. The aim of this work is to verify the approaches of the nuclear medicine techniques in the evaluation of the erectile function/disfunction. A search using the words ED and nuclear medicine, ED and scintigraphy, ED and spect and ED and pet was done in the PubMed. The number of citations in each subject was determined. Neuroimaging techniques offer insight into brain regions involved in sexual arousal and inhibition. To tackle problems such as hyposexual disorders or ED caused by brain disorders, it is crucial to understand how the human brain controls sexual arousal and penile erection.
\end{abstract}

Key-words: Nuclear medicine, erectile dysfunction, positron emission tomography, single photon emission computed tomography

\section{INTRODUCTION}

Functional imaging (metabolic images) with positron emission tomography (PET) and single photon emission computed tomography (SPECT) is capable of visualizing subtle changes in physiological function in vivo, which aids in the early diagnosis of various diseases (Wen et al., 2007). Imaging studies of sexual arousal have employing SPECT (Tiihonen et al., 1994) and PET (Rauch et al., 1999; Stoleru et al., 1999; Redoute et al., 2000) have been also published.
The widespread application of PET in clinical has driven this imaging technology into a number of new research and clinical arenas. Increasing numbers of patient scans have led to an urgent need for efficient data handling and the development of new image analysis techniques to aid clinicians in the diagnosis of disorders and planning of treatment. Automatic quantitative assessment of metabolic PET data is attractive and has certainly revolutionized the practice of functional imaging since it can lower variability across institutions and may enhance the consistency of image interpretation independent on

\footnotetext{
${ }^{*}$ Author for correspondence
} 
the reader experience (Montgomery_et al., 2007; Graves et al., 2007).

The SPECT images, as the PET, are also useful to assess the clinical conditions of a patient. A major limitation to PET and SPECT imagings in some clinical evaluations is the lack of the structural delineation of the pathologic processes they detect; this drawback sometimes renders SPECT interpretation difficult and can diminish its diagnostic accuracy. The recent development of dual-modality integrated imaging systems that provide functional (SPECT) and anatomical computed tomography (CT) images in the same scanning session, with the acquired images coregistered by means of the hardware, has opened a new era in this field. The correlation of SPECT and other modalities of images can aid in the decision-making process by enabling better localization and definition of organs and lesions and improving the precision of surgical biopsies (O'Connor and Kemp, 2006; Schillaci et al., 2007). The functional images, as PET and SPECT, have also been successfully used to evaluate the alterations of the deviant behaviour (Sumich et al., 2003), as well as, sexual disordes, like the erectile dysfunction (Tsujimura et al., 2006).

Sexuality is an important component of emotional and physical intimacy that men and women experience through their lives. About a third of the elderly population has at least one complaint with their sexual function (Camacho and Reyes-Ortiz, 2005). However, about $60 \%$ of the elderly population expresses their interest for maintaining sexual activity (Camacho and Reyes-Ortiz, 2005).

Erectile dysfunction is a common, age-related disorder that diminishes quality of life for affected men and their partners (Guay and Jacobson, 2007; Ruzic et al., 2007). While most erectile dysfunction is now recognized as organic in origin, both organic and psychogenic causes often conspire to reduce sexual function in men with erectile dysfunction (Miner and Kuritzky, 2007).

Erectile dysfunction can be defined as the total inability to achieve or maintain an erection sufficient for satisfactory sexual performance. Erectile performance has been characterized by the degree of dysfunction, and estimates of prevalence (the number of men with the condition) vary depending on the definition of erectile dysfunction used. The definition of erectile dysfunction currently used and accepted worldwide does not encompass all possible changes to male erection. Partial, temporary, or episodic absence of erection is not considered as true erectile dysfunction. This leads to a lack of diagnosis and therapy and perhaps even the risk of the subsequent development of overt impotence (Jannini et al., 2006).

The human psychosexual cycle can be categorized into four phases according to penodynamic changes: (1) excitement into latency and tumescense, (2) plateau into erection and rigidity, (3) orgasm into emission and ejaculation, and (4) resolution into detumescense and refractoriness (Govier et al., 1995; Miyagawa et al., 2007). During each phase, the specific response in neural pathway, penile hemodynamics, and functional status occurs. Identification of specific neural substrates of each phase may provide information regarding the pathophysiology of various types of sexual dysfunction originating in the brain (Miyagawa et al., 2007). The penile erection is an answer of the organism of the men related with the psychosexual cycle that has been studied by several authors, including the evaluations with functional images (Tsujimura et al., 2006; Miyagawa et al., 2007) as it is found in the PubMed.

PubMed is a service of the U.S. National Library of Medicine that includes over 16 million MEDLINE citations and other life science journals for biomedical articles back to the 1950s. PubMed, which is used as a tool in various publications, includes links to full text articles and other related resources.

The aim of this research was to verify the approaches of the nuclear medicine techniques in the evaluation of the erectile function/disfunction using publications found in the PubMed.

\section{MATERIALS AND METHODS}

The searches were performed in PubMed (http://www.ncbi.nlm.nih.gov/entrez/query.fcgi) in the period 1950 to 2007.

Searches using the words (i) erectile dysfunction and nuclear medicine, (ii) erectile dysfunction and scintigraphy, (iii) erectile dysfunction and SPECT and (iv) erectile dysfunction and PET were performed. The data were obtained on July $6^{\text {th }}$, 2007. The number of citations in each subject in the studied period was determined. We have selected some recent papers to further discussion. 


\section{RESULTS}

The PubMed search to identify the papers related with erectile dysfunction and functional images (PET and SPECT) trusing the words (i) " Erectile disfunction and nuclear medicine has yielded 18 publications; (ii) using the words "Erectile dysfunction and scintigraphy" yielded 26 articles, (iii) with "Erectile dysfunction and SPECT" were 2 articles and (iv) with "Erectile dysfunction and PET" were 3 articles.

Some published articles involving erectile dysfunction and nuclear medicine in humans were analyzed according to imaging technique of nuclear medicine used, the aim and the findings observed (table 1).

Table 1 - Details of nuclear medicine imaging studies of erectile dysfunction

\begin{tabular}{|c|c|c|}
\hline Publication & $\begin{array}{c}\text { Imaging } \\
\text { Technique }\end{array}$ & Aim \\
\hline Min J. K., 2006 & SPECT & $\begin{array}{l}\text { Determine the relationship between erectile dysfunction and coronary heart } \\
\text { disease in men referred for stress myocardial perfusion }\end{array}$ \\
\hline Ortiz J. et al., 2005 & SPECT & $\begin{array}{l}\text { Study the correlation between erectile dysfunction and myocardial perfusion } \\
\text { impairment in men with suspected or diagnosed coronary artery disease }\end{array}$ \\
\hline $\begin{array}{l}\text { Hagemann J. H. et } \\
\text { al., } 2003\end{array}$ & PET & $\begin{array}{l}\text { Investigate whether cerebral activation during visually evoked sexual } \\
\text { arousal is different in patients with erectile dysfunction compared to the } \\
\text { known pattern observed in healthy men, and additionally how cerebral } \\
\text { activity during visual sexual stimulation is modified by treatment with } \\
\text { apomorphine SL and whether the observed cerebral activity correlates with } \\
\text { penile rigidity }\end{array}$ \\
\hline $\begin{array}{l}\text { Drawz B. et al., } \\
1998\end{array}$ & SPECT & $\begin{array}{l}\text { Determine the effect on penile haemodynamics of vascularization using the } \\
\text { Hauri method for the treatment of erectile dysfunction of vascular aetiology }\end{array}$ \\
\hline $\begin{array}{l}\text { Dunn E. K. et al., } \\
1995\end{array}$ & SPECT & $\begin{array}{l}\text { Assess the role of penile scintigraphy with }(99 \mathrm{mTc}) \text { pertechnetate } / 99 \mathrm{mTc} \text { - } \\
\text { RBCs in patients with sickle cell disease patients who had priapism in } \\
\text { directing the clinical management of these patients }\end{array}$ \\
\hline $\begin{array}{l}\text { Siraj Q. H. et al., } \\
1994\end{array}$ & SPECT & $\begin{array}{l}\text { Evaluate the diagnostic value of quantitative radionuclide phallography with } \\
\text { intravenous pharmacological stress in screening impotent patients for penile } \\
\text { arterial inadequacy using technetium- } 99 \mathrm{~m} \text { labelled autologous erythrocytes }\end{array}$ \\
\hline
\end{tabular}

\section{DISCUSSION}

To our best knowledge about the mechanisms involved with the erectile dysfunction, this short review about the use od nuclear medicine images would be worthwhile. The treatment of sexual dysfunction or deviancy requires an understanding of the underlying neural substrates. Neuroimaging techniques offer insight into brain regions involved in sexual arousal and inhibition (Sumich et al., 2003). The images obtained in the nuclear medicine (PET or SPECT) are functional images and this condition is highly desired to evaluate the metabolic functions (Wen et al., 2007), as the various aspects related with the sexual activity (Tsujimura et al., 2006; Miyagawa et al., 2007). The development of robust paradigms has implications for the assessment and treatment of sexual disorder in men (Sumich et al., 2003). Penile sensory information is essential for reproduction, but almost nothing is known about how sexually salient inputs from the penis are processed in the brain (Georgiadis and Holstege, 2005). Advanced audiovisual activity with imagination, not primary visual and audio activity, occurs when men experience sexual arousal inducing penile erection. Furthermore, the cerebellar vermis may be a key region for induction of penile erection in humans (Tsujimura et al., 2006). Although various brain regions have been shown to respond to the presentation of visual sexual stimuli, whether these regions are specifically mediating sexual arousal or whether 
they mediate general emotional or motivational arousal is unknown. (Redouté et al., 2005).

Hypersexuality is a rare but well recognized condition following brain injury (Rees et al., 2007). It has been described secondarily to dysfunction in the hypothalamus, the temporal and frontal lobes. A SPECT showed frontal hypoperfusion. We believe that these findings are expression of frontal-subcortical circuits dysfunction, particularly the orbitofrontal circuit, secondary to dorso medial thalamic infarction which probably plays a role in the determination of human sexual behavior. This case favors a thalamic modulation of frontal function (Ortiz et al., 2005; Min, 2006; Mutarelli et al., 2006).

Although hypoactive sexual desire disorder is a common condition and has long been hypothesized to result from malfunctions of the cerebral control mechanisms that adjust the level of sexual motivation, very little is known about the pathophysiology of this disorder (Stoléru et al., 2003).

Radioisotope penile plethysmography is a nuclear medicine technique which assists in the evaluation of patients with erectile dysfunction. Schwartz et al., 1989 have reported that this technique attempts to noninvasively quantitate penile corpora cavernosal blood flow during early penile tumescence using technetium-99m-labeled red blood cells. The strong correlation of peak corporal flow and angiography suggests that radioisotope penile plethysmography could prove useful in the evaluation of arterial inflow disorders in patients with erectile dysfunction.

Sexual offense resulting from deviant behaviour impacts on the victim, perpetrator and society. Development of valid and reliable methods to identify offenders and assess treatment efficacy requires an understanding of the underlying neural substrates of human sexual behaviour, as the techniques used in the nuclear medicine (Sumich et al., 2003). The observations on the effect of abuse suggest a possible modulating role of abuse history on this brain response (Ringel et al., 2003). Structures implicated in arousal and/or inhibition include the hypothalamus, septal nuclei, amygdala and anterior cingulated (Sumich et al., 2003). To tackle problems such as hyposexual disorders or erectile dysfunction caused by brain disorders, it is crucial to understand how the humain brain controls sexual arousal and penile erection. Future studies will clarify the role of these structures and the neurotransmitters and neuromodulators involved (Miyagawa et al., 2007).

Patients with erectile dysfunction have higher estimated probability of presenting segmental myocardial perfusion and functional contraction impairment and, therefore, coronary artery disease and left ventricular dysfunction than those without erectile dysfunction, independent of the aging factor (Ortiz et al., 2005; Min, 2006).

Hagemann et al., 2003 have reported, using PET scans, that in patients with erectile dysfunction, the pattern of increased and decreased cerebral activity in response to visual sexual stimulation. Apomorphine SL appears to induce additional cerebral activity in the right prefrontal cortex, an area previously shown to be associated with sexual arousal in male volunteers during orgasm.

Drawz et al., 1998, using SPECT have observed the penile vascularization using the Hauri method provides an objectively demonstrable improvement in penile haemodynamics in man.

Whereas the nonstagnant scintigraphic finding appeared to be a favorable indicator for conservative treatment, the stagnant finding was apparently noncontributory (Dunn et al., 1995).

Arteriogenic impotent patients demonstrated a lesser degree of increase in penile blood flow and volume than impotent patients with uncompromised penile arterial inflow. These scintigraphic findings revealed that the quantitation of penile blood flow and volume yielded a high diagnostic accuracy $(>90 \%)$ (Siraj et al., 1994).

Concerning to the sexual function/dysfunction, it would be interesting to have some studies showing what happen and which modifications take place after drug therapy, as blood pressure medications and antidepressive and/or hormonal treatment. Moreover, the use of the nuclear medicine procedures could aid clarify the phenomena associated with the sexual function in different clinical evaluations. In conclusion, the findings reported in this work reveal the importance of the functional imaging with PET and SPECT in the evaluations of the erectile dysfunction. Furthermore, although these analysis are highly relevant, the number of publications in these subject is still well limited, at least, when an important database bank, the PubMed is used. 


\section{ACKNOWLEDGEMENTS}

The authors thank UERJ, FAPERJ and CNPq for the support.

\section{RESUMO}

Imagens functionais, como o positron emission tomography e o single photon emission computed tomography são capazes de identificar súbitas alterações fisiológicas in vivo. A disfunção erétil diminui a qualidade de vida do casal. A identificação de substratos neurais pode esclarecer a fisiopatologia dos diferentes tipos de disfunções sexuais originadas no cérebro. $\mathrm{O}$ objetivo deste trabalho é verificar a abordagem das técnicas da medicina nuclear na avaliação da função/disfunção erétil. Uma pesquisa utilizando as palavras disfunção erétil e medicina nuclear, disfunção erétil e cintigrafia, disfunção erétil e SPECT e disfunção erétil e PET foi realizada no PubMed. O número de citações em cada palavra estudada foi determinado. Técnicas de neuroimagem permitem a avaliação das regiões cerebrais durante o estímulo ou inibição sexual. Para resolver alterações como disfunções hipossexuais ou disfunção erétil causada por alterações cerebrais, é crucial entender como o cérebro controla o estímulo sexual e a ereção peniana.

\section{REFERENCES}

Camacho, M. E. and Reyes-Ortiz, C. A. (2005), Sexual dysfunction in the elderly: age or disease? Int J Impot Res., 17, Suppl 1, S52-56.

Drawz, B.; Drawz, G.; Kittner, C.; Seiter, H. and Schuemichen, C. (1998), Penile perfusion and functional scintigraphy: preliminary clinical results before and after microsurgical revascularization. $\mathrm{Br} \mathrm{J}$ Urol., 82, 241-245.

Dunn, E. K.; Miller, S. T.; Macchia, R. J.; Glassberg, K. I.; Gillette, P. N.; Sarkar, S. D. and Strashun, A. M. (1995), Penile scintigraphy for priapism in sickle cell disease. J Nucl Med., 36, 1404-1407.

Georgiadis, J. R. and Holstege, G. (2005), Human brain activation during sexual stimulation of the penis. $J$ Comp Neurol., 493, 33-38.

Govier, F. E.; Asase, D.; Hefty, T. R.; McClure, R. D.; Pritchett, T. R. and Weissman, R. M. (1995), Timing of penile color flow duplex ultrasonography using a triple drug mixture. J Urol., 153, 1472-1475.
Graves, E. E.; Quon, A. and Loo, B. W. (2007), RT_Image: an open-source tool for investigating PET in radiation oncology. Technol Cancer Res Treat., 6 , 111-121.

Guay, A. and Jacobson, J. (2007), The relationship between testosterone levels, the metabolic syndrome (by two criteria), and insulin resistance in a population of men with organic erectile dysfunction. J Sex Med., 4, 1046-1055.

Hagemann, J. H.; Berding, G.; Bergh, S.; Sleep, D. J.; Knapp, W. H.; Jonas, U. and Stief, C. G. (2003), Effects of visual sexual stimuli and apomorphine SL on cerebral activity in men with erectile dysfunction. Eur Urol., 43, 412-420.

Jannini, E. A.; Lenzi, A.; Isidori, A. and Fabbri, A. (2006), Subclinical erectile dysfunction: proposal for a novel taxonomic category in sexual medicine. $J$ Sex Med., 3, 787-793.

Min, J. K.; Williams, K. A.; Okwuosa, T. M.; Bell, G. W.; Panutich, M. S. and Ward, R. P. (2006), Prediction of coronary heart disease by erectile dysfunction in men referred for nuclear stress testing. Arch Intern Med., 166, 201-206.

Miner, M. M. and Kuritzky, L. (2007), Erectile dysfunction: a sentinel marker for cardiovascular disease in primary care. Cleve Clin J Med., 74 Suppl 3, S30-77.

Miyagawa, Y.; Tsujimura, A.; Fujita, K.; Matsuoka, Y.; Takahashi, T.; Takao, T.; Takada, S.; Matsumiya, K.; Osaki, Y.; Takasawa, M.; Oku, N.; Hatazawa, J.; Kaneko, S. and Okuyama, A. (2007), Differential brain processing of audiovisual sexual stimuli in men: comparative positron emission tomography study of the initiation and maintenance of penile erection during sexual arousal. Neuroimage., 36, 830-842.

Montgomery, D. W.; Amira, A. and Zaidi, H. (2007), Fully automated segmentation of oncological PET volumes using a combined multiscale and statistical model. Med Phys., 34, 722-736.

Mutarelli, E. G.; Omuro, A. M. and Adoni, T. (2006), Hypersexuality following bilateral thalamic infarction: case report. Arq Neuropsiquiatr., 64, 146148.

O'Connor, M. K. and Kemp, B. J. (2006), Singlephoton emission computed tomography/computed tomography: basic instrumentation and innovations. Semin Nucl Med., 36, 258-266.

Ortiz, J.; Ortiz, S. T.; Mônaco, C. G., Yamashita, C. H.; Moreira, M. C. and Monaco, C. A. (2005), Erectile dysfunction: a marker for myocardial perfusion impairment? Arq Bras Cardiol., 85, 241-246.

Rauch, S. L.; Shin, L. M.; Dougherty, D. D.; Alpert, N. M.; Orr, S. P.; Lasko, M.; Macklin, M. L.; Fischman, A. J. and Pitman, R. K. (1999), Neural activation during sexual and competitive arousal in healthy men. Psychiatry Res., 30, 1-10.

Redouté, J.; Stoléru, S.; Grégoire, M. C.; Costes, N.; Cinotti, L.; Lavenne, F.; Le Bars, D.; Forest, M. G. 
and Pujol, J. F. (2000), Brain processing of visual sexual stimuli in human males. Hum Brain Mapp., 11, 162-177.

Redouté, J.; Stoléru, S.; Pugeat, M.; Costes, N.; Lavenne, F.; Le Bars, D.; Dechaud, H.; Cinotti, L. and Pujol, J. F. (2005), Brain processing of visual sexual stimuli in treated and untreated hypogonadal patients. Psychoneuroendocrinology., 30, 461-482.

Rees, P.M.; Fowler, C.J. and Maas, C. P. (2007), Sexual function in men and women with neurological disorders. Lancet., 369, 512-525.

Ringel, Y.; Drossman, D. A.; Turkington, T. G.; Bradshaw, B.; Hawk, T. C.; Bangdiwala, S.; Coleman, R. E. and Whitehead, W. E. (2003), Regional brain activation in response to rectal distension in patients with irritable bowel syndrome and the effect of a history of abuse. Dig Dis Sci., 48, 1774-1781.

Ruzié, A.; Persić, V.; Miletić, B.; Vcev, A.; Mirat, J.; Soldo, I.; Batinac, T. and Kovac, T. (2007), Erectile dysfunction after myocardial infarction-myth or a real problem? Coll Antropol., 31, 185-188.

Schwartz, A. N.; Graham, M. M.; Ferency, G. F. and Miura, R. S. (1989), Radioisotope penile plethysmography: a technique for evaluating corpora cavernosal blood flow during early tumescence. $J$ Nucl Med., 30, 466-473.
Siraj, Q. H. and Hilson, A. J. (1994), Diagnostic value of radionuclide phallography with intravenous vasodilator stress in the evaluation of arteriogenic impotence. Eur J Nucl Med., 21, 651-657.

Stoléru, S.; Grégoire, M. C.; Gérard, D.; Decety, J.; Lafarge, E.; Cinotti, L.; Lavenne, F.; Le Bars, D.; Vernet-Maury, E.; Rada, H.; Collet, C.; Mazoyer, B.; Forest, M. G.; Magnin, F.; Spira, A. and Comar, D. (1999), Neuroanatomical correlates of visually evoked sexual arousal in human males. Arch Sex Behav., 28, 1-21.

Stoléru, S.; Redouté, J.; Costes, N.; Lavenne, F.; Bars, D. L.; Dechaud, H.; Forest, M. G.; Pugeat, M.; Cinotti, L. and Pujol, J. F. (2003), Brain processing of visual sexual stimuli in men with hypoactive sexual desire disorder. Psychiatry Res., 124, 67-86.

Sumich, A. L.; Kumari, V. and Sharma, T. (2003), Neuroimaging of sexual arousal: research and clinical utility. Hosp Med., 64, 28-33.

Tiihonen, J.; Kuikka, J.; Kupila, J.; Partanen, K.; Vainio, P.; Airaksinen, J.; Eronen, M.; Hallikainen, T.; Paanila, J. and Kinnunen, I. (1994), Increase in cerebral blood flow of right prefrontal cortex in man during orgasm. Neurosci Lett., 170, 241-243.

Tsujimura, A.; Miyagawa, Y.; Fujita, K.; Matsuoka, Y.; Takahashi, T.; Takao, T.; Matsumiya, K.; Osaki, Y.; Takasawa, M.; Oku, N.; Hatazawa, J.; Kaneko, S. and Okuyama, A. (2006), Brain processing of audiovisual sexual stimuli inducing penile erection: a positron emission tomography study. J Urol., 176, 679-683.

Wen, L.; Eberl, S.; Choi, H. C.; Feng, D. D. and Fulham, M. (2007), Enhanced parameter estimation methods for noisy SPECT data. Comput Methods Programs Biomed., (in press). 